studies and research in Western Germany ('Stand und Aufgaben der Deutschen AfrikaWissenschaft ') was attempted, the proceedings of which have just been published.

\title{
Second International Conference of Ethiopian Studies
}

The First International Conference of Ethiopian Studies was held in Rome in 1959, under the auspices of the Accademia dei Lincei. The Second International Conference will take place in the University of Manchester from Monday afternoon, 8 July, to Thursday noon, II July 1963. Apart from the usual conference activities, papers, and discussions, members will be able to see the collections of the John Rylands Library, Manchester, including some as yet uncatalogued items in the field of Ethiopic manuscripts. It is hoped to have a small number of full-length papers ( 50 minutes), followed by a detailed discussion, as well as a somewhat larger number of brief communications (IO-Is minutes). Any subject within the sphere of Ethiopian studies will be acceptable. The Conference languages will be English, French, Italian, Amharic, and German. Further particulars may be obtained from: Professor Edward Ullendorff, Department of Near Eastern Studies, University of Manchester, Manchester I3.

\section{Symposium on Systems of African Land Control}

The Centre d'Étude de Droit Comparé Africain of Lovanium University will organize a symposium on African land control, from 1 to ro April 1963 , in the University Campus at Leopoldville.

All countries south of the Sahara are confronted with the problem of land control, and the aim of CÉDCA is to bring together, on African soil, jurists versed in this subject, so as to draw up an objective dossier on the problem and to put it at the disposal of interested governments and administrations.

With this aim in mind, the following points will be examined: (a) land control in the customary African systems; (b) the main methods of land control under colonial law; (c) the main sytems of land control in force abroad; (d) new legislation (proposed or already in effect) in the independent African states.

In order that the symposium may retain its detached scientific character, only those scholars invited to the discussion will be admitted to full participation. Land-control agents and others interested in these problems will be admitted as observers. 